\title{
ERRATUM
}

\section{Erratum to: Impact of Participation in the Adalimumab (Humira) Patient Support Program on Rheumatoid Arthritis Treatment Course: Results from the PASSION Study}

Filip Van den Bosch · Andrew J. K. Ostor - Siegfried Wassenberg •

Naijun Chen · Chen Wang · Vishvas Garg · Jasmina Kalabic

Published online: May 4, 2017

(c) The Author(s) 2017. This article is an open access publication

Erratum to: Rheumatol Ther

DOI 10.1007/s40744-017-0061-7

In the original publication, $\mathrm{ADA}$ treatment values mentioned in the results section, under the heading 'Study Outcomes' were published incorrectly.

The correct text should read "Additionally, compared to PSP users, PSP non-users had significantly lower percentage of patients that started at PAM-13 level 4 at baseline and remained at level 4 until week 78 of ADA treatment $(52.4 \% \text { vs } 28.9 \%, p=0.001)^{\prime \prime}$.

The online version of the original article can be found under doi:10.1007/s40744-017-0061-7.

F. Van den Bosch $(\bowtie)$

Ghent University Hospital and VIB Center for Inflammation Research, Ghent, Belgium e-mail: filip.vandenbosch@ugent.be

\section{A. J. K. Ostor}

Addenbrooke's Hospital, Cambridge, UK

S. Wassenberg

Rheumazentrum, Ratingen, Germany

N. Chen · C. Wang · V. Garg

AbbVie Inc., North Chicago, IL, USA

J. Kalabic

AbbVie Deutschland GmbH \& Co. KG,

Ludwigshafen, Germany
Open Access. This article is distributed under the terms of the Creative Commons Attribution-NonCommercial 4.0 International License (http://creativecommons.org/licenses/ by-nc/4.0/), which permits any noncommercial use, distribution, and reproduction in any medium, provided you give appropriate credit to the original author(s) and the source, provide a link to the Creative Commons license, and indicate if changes were made. 